\title{
PENGARUH MANAJEMEN LABA TERHADAP NILAI PERUSAHAAN DENGAN CORPORATE GOVERNANCE SEBAGAI VARIABEL PEMODERASI
}

\author{
Hernadianto $^{1}$, Ade Oktarina ${ }^{2}$ \\ ${ }^{12}$ Program Studi Akuntansi' Universitas Muhammadiyah Bengkulu \\ hernadianto@umb.ac.id, adeoktarina29@gmail.com
}

\begin{abstract}
ABSTRAK
Nilai perusahaan yang tinggi dapat meningkatkan kemakmuran bagi para pemegang saham sehingga mereka akan menginvestasikan dananya ke dalam saham perusahaan tersebut yang menyebabkan manajemen perusahaan cenderung melakukan praktik manajemen laba dan dapat diatasi atau diminimumkan dengan pengawasan sendiri melalui corporate governance. Tujuan penelitian ini adalah membuktikan pengaruh manajemen laba terhadap nilai perusahaan, corporate governance yang diproksi kepemilikan manajerial, kepemilikan institusional, proporsi dewan komisaris independen, Kualitas audit terhadap hubungan antara manajemen laba terhadap nilai perusahaan pada perusahaan manufaktur di Bursa Efek Indonesia. Metode Penelitian adalah kuantitatif dan Jenis data adalah sekunder yaitu laporan keuangan perusahaan manufaktur di Bursa Efek Indonesia selama periode 2013-2015. Sampel penelitian metode purposive sampling, ditemukan 40 perusahaan yang masuk kriteria. Pengujian hipotesis dilakukan dengan menggunakan analisis regresi linier berganda untuk menguji pengaruh simultan dari beberapa variabel bebas terhadap satu variabel terikat. Hasil penelitian Membuktikan bahwa manajemen laba dapat menaikkan nilai perusahaan. Variabel moderasi yang mempengaruhi hubungan dari manajemen laba terhadap nilai perusahaan adalah kepemilikan manajerial dan kepemilikan institusional. Sedangkan proporsi dewan komisaris independen, dan kualitas audit bukan merupakan variabel moderasi.
\end{abstract}

\section{Kata Kunci : Manajemen Laba, Nilai Perusahaan, Corporate Governance, Kepemilikan Manajerial, Kepemilikan Institusional, Proporsi Dewan Komisaris Independen, Kualitas Audit}

\begin{abstract}
High corporate values can increase the prosperity of shareholders so that they will invest their capital into the company's stock which causes the company's management to practice earnings management and can be overcome or minimized with its own supervision through corporate governance. The purpose of this research is to prove the influence of earnings management on corporate value, corporate governance with managerial ownership, institutional ownership, proportion of independent board of commissioner, audit quality to the relationship between earnings management to company value at manufacturing company in Indonesia Stock Exchange. This research uses quantitative method and the data used is secondary data which is financial report of manufacturing company in Bursa Efek Indonesia during period 2013-2015. The sample in research using purposive sampling method, found 40 companies that enter the criteria. Hypothesis testing is done by using multiple linear regression analysis to test the simultaneous influence of sever The results prove that earnings management can raise the value of the company. The moderating variables that affect the relationship of earnings management to firm value are managerial ownership and institutional ownership. While the proportion of independent board of commissioners, and audit quality is not a moderating variable.
\end{abstract}

Keywords : Earnings management, corporate value, corporate governance, managerial ownership, institutional ownership, proportion of independent board of commissioners, audit quality al independent variables on one dependent variable. 


\section{PENDAHULUAN}

Perusahaan merupakan suatu organisasi yang terdiri atas sekelompok orang yang bekerja untuk mencapai tujuan yaitu meningkatkan nilai perusahaan adalah sebuah prestasi, yang sesuai dengan keinginan para pemiliknya, meningkatnya nilai perusahaan, maka kesejahteraan para pemilik juga akan meningkat. Peningkatan kualitas dari laporan keuangan di suatu perusahaan dapat di lihat dari perilaku praktik manajemen laba. Tujuan manajemen laba adalah meningkatkan kesejahteraan pihak tertentu yang dapat diidentifikasi sebagai suatu keuntungan (Fisher dan Rosenzweig 1995; Scot 1997:294 dalam Herawaty 2008). Manajemen laba yang dilakukan manajemen perusahaan akan meningkatkan nilai perusahaan (Tobin's Q) (Morck et al., 1988). Praktik manajemen laba dapat diatasi atau diminimumkan dengan pengawasan sendiri melalui good corporate governance. Forum for Corporate governance in Indonesia (FCGI,2001) mendefinisikan corporate governance sebagai suatu perangkat peraturan yang menetapkan hubungan antara pemegang saham, pengurus, pihak kreditur, pemerintah, karyawan serta pemegang kepentingan internal dan eksternal lainnya sehubungan dengan hakhak dan kewajiban mereka.

Beberapa penelitian lainnya juga telah meneliti hubungan dari beberapa mekanisme corporate governance, dari penelitian Murhadi (2009) yang meneliti pengaruh praktek Good Governance terhadap praktik manajemen laba oleh perusahaan, hasil penelitian ini menunjukkan bahwa hanya dua variabel berpengaruh signifikan terhadap prakti manajemen laba yaitu $C E O$ duality dan keberadaan pemegang saham pengendali. Penelitian ini menggunakan sampel perusahaan manufaktur yang terdaftar di Bursa Efek Indonesia periode 2005-2007. Sedangkan, Herawaty (2008) yang meneliti hubungan antara manajemen laba terhadap nilai perusahaan dengan corporate governance sebagai variabel pemoderasinya. Penelitian ini menggunakan sampel perusahaan non keuangan yang terdaftar di Bursa Efek Jakarta pada tahun 2004-2006.

Berdasarkan hasil penelitian terdahulu yang telah diuraikan diatas, dapat diketahui bahwa adanya perbedaan dari hasil penelitian-penelitian sebelumnya, oleh karena itu peneliti tertarik untuk menguji kembali variabel-variabel tersebut dengan periode yang berbeda, penelitian ini dilakukan diseluruh perusahaan manufaktur yang terdaftar dalam Bursa Efek Indonesia. Variabel-variabel yang di uji dalam penelitian ini adalah nilai perusahaan sebagai variabel dependen yang di ukur menggunakan rasio Tobin's $Q$ yang merupakan konsep yang berharga karena dapat menunjukkan estimasi pasar keuangan saat ini tentang nilai hasil pengembalian setiap dana yang diinvestasikan. Variabel independen dalam penelitian ini adalah manajemen laba yang diukur dengan proksi discretionary accruals. Discretionary accruals (DA) adalah komponen akrual yang memungkinkan manajer untuk melakukan intervensi dalam penyusunan laporan keuangan, sehingga laba yang dilaporkan dalam laporan keuangan tidak mencerminkan nilai atau kondisi perusahaan yang sesungguhnya (Guna dan Herawaty, 2010:56). Variabel moderasi dalam penelitian ini adalah corporate governance yang terdiri dari Kepemilikan Manajerial, Kepemilikan Institusional, proporsi Dewan Komisaris Indpenden, dan kualitas Audit. Komite Nasional Kebijakan Governance (KNKG, 2004) menyatakan bahwa corporate governance merupakan suatu proses dan struktur yang digunakan oleh organ perusahaan untuk memberikan nilai tambah pada perusahaan secara berkesinambungan dalam jangka panjang bagi pemegang saham, dengan tetap memperhatikan kepentingan stakeholders, berlandaskan peraturan perundang-undangan dan norma yang berlaku. Sedangkan Variabel kontrol yang digunakan dalam penelitian ini adalah ukuran Perusahaan yang dapat diukur dari natural logaritma natural total aktiva perusahaan pada akhir tahun yaitu jumlah saham beredar 
pada akhir tahun dikalikan dengan harga pasar saham akhir tahun. Dalam mempermudah penelitian ini maka penelitian ini hanya dilakukan pada perusahaan manufaktur yang mengalami laba selama tiga tahun berturut-turut dan memiliki data mengenai corporate governance saja, karena perusahaan manufaktur di Bursa Efek Indonesia memiliki jumlah yang lebih banyak, sehingga akan mempermudah peneliti dalam memilih sampel dan memperoleh data. Supaya penelitian ini memiliki data yang yang lebih up to date dari penelitian sebelumnya maka peneliti menggunakan periode terbaru yaitu 2013-2015 dengan judul "Pengaruh Manajemen Laba Terhadap Nilai Perusahaan Dengan Corporate Governance Sebagai Variabel Pemoderasi”

\section{TINJAUAN LITERATUR DAN PERUMUSAN HIPOTESIS}

Teori keagenan menjelaskan bahwa hubungan agensi terjadi ketika pemegang saham (principal) memperkerjakan manajer (agent) untuk memberikan suatu jasa dan kemudian mendelegasikan wewenang untuk pengambilan keputusan kepada agent. Menurut Eisenhardt (dalam Dyas Tri Pamungkas, 2012) menyatakan bahwa Teori Keagenan menggunakan tiga asumsi dasar sifat manusia yaitu : (1) manusia pada umumnya mementingkan dirinya sendiri (self interest), (2) manusia memiliki daya pikir terbatas mengenai persepsi masa mendatang (bounded rationaly), dan (3) manusia selalu menghindari risiko (risk adverse). Berdasarkan asumsi dasar manusia tersebut manajer sebagai manusia akan bertindak opportunistic, yaitu manajer akan berusaha semampu mereka untuk memprioritaskan pencapaian kepentingannya sendiri.

Manajer sebagai pengelola perusahaan memiliki lebih banyak informasi internal perusahaan dan prospek perusahaan di masa mendatang dibandingkan dengan pemegang saham. Oleh karena itu manajer berkewajiban memberikan sinyal kepada pemegang saham. Sinyal tersebut dapat diberikan dalam bentuk pengungkapan informasi akuntansi seperti laporan keuangan. Situasi ini akan memicu timbulnya asymetri informasi yaitu kondisi ketidak seimbangan perolehan informasi antara manajer perusahaan dan pemegang saham. Menurut Scott terdapat dua macam asimetri informasi yaitu:

1. Adverse selection, yaitu bahwa para manajer serta orang-orang dalam lainnya pada dasarnya mengetahui lebih banyak tentang keadaan dan prospek perusahaan dibandingkan pemegang saham atau pihak luar. Dan informasi yang mengandung fakta yang akan digunakan pemegang saham untuk mengambil keputusan tidak diberikan seutuhnya oleh manajer.

2. Moral hazard, yaitu bahwa kegiatan yang dilakukan oleh seorang manajer tidak seluruhnya diketahui oleh pemegang saham maupun pemberi pinjaman. Sehingga manajer dapat melakukan tindakan diluar pengetahuan pemegang saham yang melanggar kontrak dan sebenarnya secara etika atau norma tidak layak dilakukan.

Kondisi asymetri informasi tersebut dapat menimbulkan konflik kepentingan di antara manajer sebagai agent dan pemegang saham sebagai principal sehingga memungkinkan manajer untuk melakukan tindakan yang menyimpang seperti manajemen laba. Manajemen laba tersebut biasanya dilakukan oleh manajer dalam rangka meningkatkan nilai perusahaan.

\section{Corporate Governance}

Forum for Corporate governance in Indonesia (FCGI,2001) mendefinisikan corporate governance sebagai suatu perangkat peraturan yang menetapkan hubungan antara pemegang saham, pengurus, pihak kreditur, pemerintah, karyawan serta pemegang kepentingan internal dan eksternal lainnya sehubungan dengan hak-hak dan kewajiban mereka. Komite Nasional 
Kebijakan Governance (KNKG, 2004) menyatakan bahwa corporate governance merupakan suatu proses dan struktur yang digunakan oleh organ perusahaan untuk memberikan nilai tambah pada perusahaan secara berkesinambungan dalam jangka panjang bagi pemegang saham, dengan tetap memperhatikan kepentingan stakeholders lainnya, berlandaskan peraturan perundang-undangan dan norma yang berlaku (Soerzawa et al., 2018). Berdasarkan definisidefinisi tersebut dapat disimpulkan bahwa corporate governance adalah seperangkat peraturan yang mengatur hubungan diantara berbagai pihak dalam perusahaan sehubungan dengan hakhak dan kewajiban mereka dengan tujuan mencapai kepentingan pemegang saham dalam jangka panjang dengan tetap memperhatikan kepentingan semua pihak (Yusmaniarti, , 2020)

\section{Manajemen Laba}

Healy dan Wahlen mendefinisikan manajemen laba muncul ketika manajer menggunakan keputusan tertentu dalam pelaporan keuangan dan mengubah transaksi untuk mengubah laporan keuangan untuk menyesatkan stakeholder yang ingin mengetahui kinerja ekonomi yang diperoleh perusahaan atau untuk mempengaruhi hasil kontrak yang menggunakan angka-angka akuntansi yang dilaporkan itu. Ortega dan Grant menyatakan bahwa manajemen laba terjadi karena adanya kemungkinan fleksibilitas dalam membuat laporan keuangan untuk mengatur keuntungan operasional perusahaan.

Menurut Sugiri manajemen laba dapat dilakukan dengan berbagai pola yang berbeda, yaitu;

1. Taking a bath yaitu dengan mengakui biaya yang akan ditanggung pada periode yang akan datang saat periode berjalan.

2. Income minimization. Pola ini mungkin dipilih manajer perusahaan karena nampak secara politis perusahaan selalu mendapatkan keuntungan yang besar. Pola ini dilakukan saat perusahaan tidak ingin menanggung biaya politis akibat keuntungan besar yang diperolehnya.

3. Income maximization. Manajer memilih pola ini karena keinginannya untuk mendapatkan bonus dari laba besar yang dilaporkannya di laporan keuangan perusahaan.

4. Income smoothing. Pola ini dipilih oleh manajer karena mereka cenderung memilih untuk melaporkan tren perubahan laba yang stabil daripada laba yang meningkat dan menurun secara drastis. Salah satu teknik untuk meratakan laba adalah dengan mengurangi nilai persediaan dan aktiva lain perusahaan yang diperoleh pada saat akuisisi yang akan menghasilkan laba tinggi ketika aktiva tersebut nanti dijual.

Murhadi (2009) menyatakan bahwa metode yang paling sering digunakan untuk menilai tingkat manajemen laba yang dilakukan oleh perusahaan adalah metode discretionary accrual. Jumlah discretionary accrual yang positif menunjukkan bahwa perusahaan melakukan peningkatan manajemen laba.

\section{Nilai Perusahaan}

Nilai perusahaan dapat dilihat dari kinerja perusahaan. Penilaian kinerja perusahaan dapat dinilai dari segi analisis laporan keuangan berupa rasio keuangan dan dari segi perubahan harga saham . Nilai perusahaan pada dasarnya diukur dari beberapa aspek salah satunya adalah harga pasar saham perusahaan karena dapat mencerminkan penilaian investor atas keseluruhan ekuitas yang dimiliki perusahaan tersebut (Wahyudi dan Pawesti, 2006). Untuk mengukur nilai perusahaan ada beberapa rasio yang dapat digunakan, salah satu alternatif yang dapat digunakan 
adalah dengan menggunakan rasio Tobin's $Q$. Rasio ini dikembangkan oleh Profesor James Tobin (1967) dan dinilai dapat memberikan informasi yang paling baik, karena rasio ini dapat menjelaskan berbagai fenomena yang terjadi dalam perusahaan seperti terjadinya perbedaan crossectional dalam pengambilan keputusan investasi. Jika rasio' $Q$ diatas satu, ini menunjukkan bahwa investasi dalam aktiva menghasilkan laba yang memberikan nilai yang lebih tinggi daripada pengeluaran investasi sehingga akan menarik munculnya investasi baru sedangkan jika rasio'Q dibawah satu menunjukkan bahwa investasi dalam aktiva tidak menarik investor untuk memberikan investasinya yang baru (Yusmaniarti, Setiorini, 2019)

\section{METODE PENELITIAN}

\section{Populasi dan Sampel}

Populasi dalam penelitian ini adalah seluruh perusahaan manufaktur yang terdaftar di Bursa Efek Indonesia pada tahun 2013-2015, dari populasi tersebut maka akan diambil sampel sebagai penelitian. Teknik pengambilan sampel dalam penelitian ini adalah purposive sampling, Penelitian ini populasi dan sampelnya adalah 144 perusahaan Manufaktur yang tercatat di BEI.

\section{Metode Pengumpulan Data}

Metode pengumpulan data yang digunakan dalam penelitian ini adalah metode dokumentasi, yaitu pengumpulan data yang dilakukan dengan cara mempelajari catatan-catatan atau dokumen penting perusahaan berupa laporan keuangan perusahaan manufaktur.

\section{Teknik Analisis Data}

Dalam penelitian ini metode analisis yang akan digunakan meliputi statistik deskriptif, uji asumsi klasik, analisis regresi linier berganda dan variabel moderating menggunakan uji residual, selanjutnya pengujian terakhir adalah uji hipotesis dan alat yang digunakan untuk mengolah data ini adalah SPSS Versi 16.

\section{HASIL DAN PEMBAHASAN}

\section{Gambaran Umum Objek Penelitian}

Dengan kriteria yang telah ditetapkan maka jumlah sampel dalam penelitian ini berjumlah 40 perusahaan dengan jumlah observasi sebanyak 143 Observasi (Lampiran 1). Adapun nama perusahaan yang dijadikan sampel tahun pengamatan dapat dilihat pada tabel 1 :

Tabel 1. Populasi dan Sampel

\begin{tabular}{|l|c|}
\hline Perusahaan Sampel Penelitian & Jumlah Perusahaan \\
\hline $\begin{array}{l}\text { Perusahaan manufaktur yang terdaftar di Bursa Efek Indonesia } \\
\text { (BEI) dari tahun 2013-2015 }\end{array}$ & 143 \\
\hline $\begin{array}{l}\text { Laporan Keuangan yang tidak dapat diperoleh/ perusahaan yang } \\
\text { baru listing }\end{array}$ & 3 \\
\hline $\begin{array}{l}\text { Laporan keuangan yang tidak memiliki kelengkapan data untuk } \\
\text { semua variabel }\end{array}$ & 17 \\
\hline laporan keuangan yang disajikan dalam mata uang dollar & 3 \\
\hline Laporan keuangan yang menerbitkan dua jenis saham atau lebih & 40 \\
\hline $\begin{array}{l}\text { Jumlah perusahaan yang memenuhi kriteria penelitian dan } \\
\text { dijadikan sampel penelitian }\end{array}$ & \\
\hline
\end{tabular}

Sumber : Data Sekunder diolah Tahun, 2017 


\section{Statistik Deskriptif}

Statistik deskriptif merupakan bagian dari analisis data yang memberikan gambaran awal setiap variabel yang digunakan dalam penelitian. Gambaran variabel- variabel dapat dilihat dari nilai maksimum, minimum, rata-rata dan standar deviasi. Hasil statistik deskriptif dalam penelitian ini dapat dilihat pada tabel 2 sebagai berikut:

Tabel 2. Statistik Deskriptif

Descriptive Statiptics

\begin{tabular}{|c|c|c|c|c|c|}
\hline & $\mathrm{N}$ & Minimum & Maximum & bean & Std. Deviation \\
\hline $3 \mathrm{sip}^{2}$ & $6 \pi$ & $\infty$ & $B$ & Axs & .58200 \\
\hline 结 & 128 & -astea & g:1753 & -5.18 & "36ptorso \\
\hline$k$ & \&35 & 30 & $B F$ & 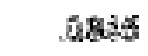 & A ARำ \\
\hline 纸 & 15 & .6 & , 20 & thos? & A난? \\
\hline thmovi? & isin & and & 步政 & अFR & , \\
\hline 谁 & in & .98 & 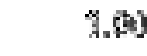 & 2920 & . At:3a \\
\hline $4 \%$ & 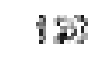 & 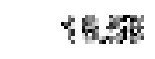 & acts & 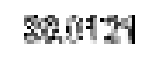 & 20925 \\
\hline 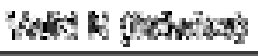 & 1293 & & & & \\
\hline
\end{tabular}

\section{Hipotesis dan pembahasan}

\section{Manajemen laba berpengaruh positif terhadap nilai perusahaan}

Dibawah ini adalah hasil uji hipotesis dalam penelitian ini dapat dilihat pada tabel 4.3 sebagai berikut :

\begin{tabular}{|c|c|c|c|c|c|c|}
\hline \multicolumn{7}{|c|}{ Costrieints: } \\
\hline \multirow{2}{*}{\multicolumn{2}{|c|}{ 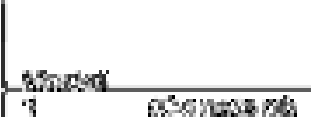 }} & \multicolumn{2}{|c|}{ 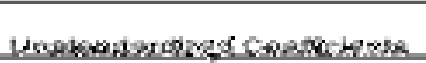 } & \multirow{2}{*}{ 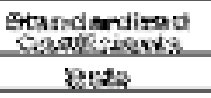 } & \multirow[b]{2}{*}{$t$} & \multirow[b]{2}{*}{946} \\
\hline & & 쪼 & PWA Kars: & & & \\
\hline ' & 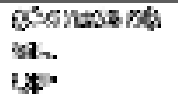 & 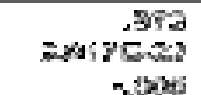 & $\begin{array}{l}-504 \\
\text { Aos }\end{array}$ & $=$ & 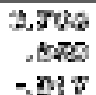 & 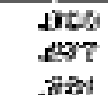 \\
\hline
\end{tabular}

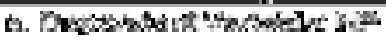

Hipotesis (H1) dengan model regresi $\mathbf{N P}=\boldsymbol{\alpha}+\boldsymbol{\beta 1} \mathbf{M L}+\boldsymbol{\beta 2} \mathbf{U P}$, dalam penelitian ini menyebutkan bahwa manajemen laba tidak berpengaruh signifikan terhadap nilai perusahaan. Hasil pengujian ini diperoleh nilai adjusted $\mathrm{R}^{2}$ sebesar 0.006 , nilai $\mathrm{f}$ hitung sebesar 0.650 , memiliki t hitung sebesar 0.559 , dan tingkat signifikan sebesar 0.577 untuk manajemen laba dan 0.361 untuk ukuran perusahaan. ketentuan pengambilan keputusan hipotesis diterima atau ditolak didasarkan pada besarnya nilai signifikansi. Jika nilai signifikansi lebih kecil dari 0.05 maka hipotesis diterima, begitu juga sebaliknya apabila nilai signifikansi lebih besar maka hipotesis ditolak.

Hasil penelitian ini diperoleh nilai signifikansi sebesar 0.577 lebih besar dari 0.05 maka disimpulkan bahwa hipotesis (H1) yaitu manajemen laba tidak berpengaruh signifikan terhadap nilai perusahaan sedangkan ukuran perusahaan juga tidak berpengaruh terhadap nilai perusahaan. Hasil penelitian ini mendukung hasil penelitian yang dilakukan oleh Herawaty (2008) dan Dyas Tri Pamungkas (2012) yang menyatakan bahwa manajemen laba tidak berpengaruh signifikan terhadap nilai perusahaan. 
Kepemilikan manajerial memoderasi hubungan antara manajemen laba dan nilai perusahaan

Dibawah ini adalah hasil uji moderasi dalam penelitian ini dapat dilihat pada tabel 4.4 sebagai berikut :

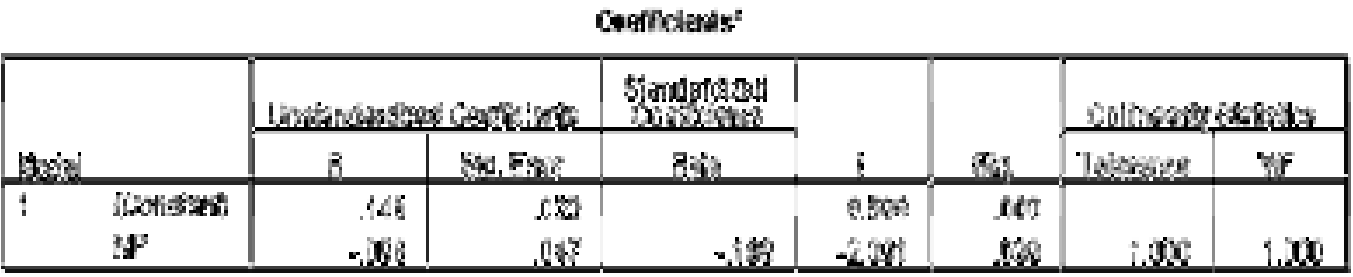

2. 12,

Hipotesis (H2) untuk menguji variabel moderasi memiliki dua model regresi yaitu : $\mathbf{K M}=\boldsymbol{\alpha}+$ $\boldsymbol{\beta 1 M L}$ dan $|\boldsymbol{\varepsilon}|=\boldsymbol{\alpha}+\boldsymbol{\beta 1 N P}$. Hasil uji moderasi diperoleh nilai adjusted $\mathrm{R}^{2}$ sebesar 0.028 , nilai $\mathrm{f}$ hitung sebesar 4.372, dan thitung -2.092 dengan tingkat signifikansi 0.039 lebih kecil dari 0.05, maka dapat disimpulkan bahwa variabel kepemilikan manajerial merupakan variabel moderasi.

Hasil penelitian ini menunjukkan bahwa kepemilikan manajerial sebagai variabel moderasi dari hubungan antara manajemen laba terhadap nilai perusahaan. kepemilikan manajerial terbukti merupakan variabel pemoderasi terhadap hubungan antara variabel manajemen laba dan nilai perusahaan, karena variabel kepemilikan manajerial memiliki nilai signifikan sehingga variabel kepemilikan manajerial dapat dikatakan sebagai variabel pemoderasi.Hasil penelitian ini mendukung hasil penelitian yang dilakukan oleh Herawaty (2008) dan Dyas Tri Pamungkas (2012) bahwa kepemilikan manajerial dapat memperkuat hubungan dari manajemen laba dan nilai perusahaan, dengan kata lain semakin besar kepemilikan manajerial maka penggunaan manajemen laba oleh manajer dapat semakin menurunkan nilai perusahaan.

\section{Kepemilikan institusional memoderasi hubungan antara manajemen laba dan nilai perusahaan}

Dibawah ini adalah hasil uji moderasi dalam penelitian ini dapat dilihat pada tabel 4.5 sebagai berikut :

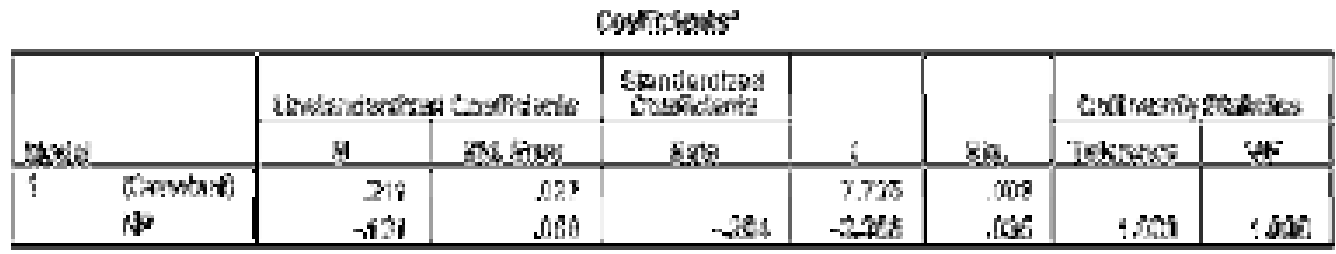

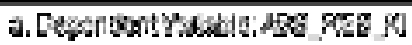

Hipotesis (H3) untuk menguji variabel moderasi memiliki dua model regresi yaitu : KI $=\boldsymbol{\alpha}+\boldsymbol{\beta 1 M L}$ dan $|\boldsymbol{\varepsilon}|=\boldsymbol{\alpha}+\boldsymbol{\beta 1 N P}$. Hasil uji moderasi diperoleh nilai adjusted $\mathrm{R}^{2}$ sebesar 0.034, nilai f hitung sebesar 5.136, dan t hitung -2.266 dengan tingkat signifikansi 0.025 lebih kecil dari 0.05 , maka dapat disimpulkan bahwa variabel kepemilikan institusional merupakan variabel moderasi.

Hasil penelitian ini menunjukkan bahwa kepemilikan institusional sebagai variabel moderasi dari hubungan antara manajemen laba terhadap nilai perusahaan. kepemilikan institusional terbukti merupakan variabel pemoderasi terhadap hubungan antara variabel 
manajemen laba dan nilai perusahaan, karena variabel kepemilikan institusional memiliki nilai signifikan sehingga variabel kepemilikan institusional dapat dikatakan sebagai variabel pemoderasi.

Hasil penelitian ini mendukung hasil penelitian yang dilakukan oleh Herawaty (2008) bahwa kepemilikan institusional dapat memperkuat hubungan dari manajemen laba dan nilai perusahaan, dengan kata lain semakin besar kepemilikan institusional maka penggunaan manajemen laba oleh manajer dengan investor dapat membuat pemilik saham institusional merasa puas atas kinerja manajerial, dimana hal ini dapat menurunkan nilai perusahaan.

\section{Proporsi dewan komisaris independen memoderasi hubungan antara manajemen laba dan nilai perusahaan}

Dibawah ini adalah hasil uji moderasi dalam penelitian ini dapat dilihat pada tabel 4.6 sebagai berikut :

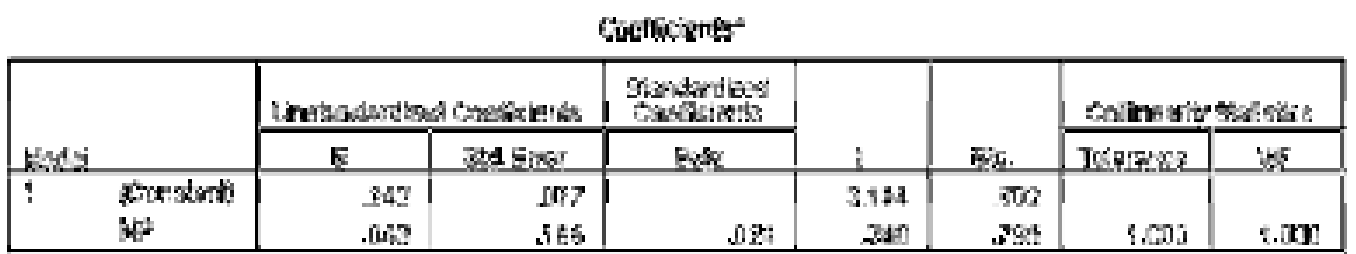

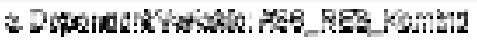

Hipotesis (H4) untuk menguji variabel moderasi memiliki dua model regresi yaitu : Komind $=\boldsymbol{\alpha}+\boldsymbol{\beta 1 M L}$ dan $|\boldsymbol{\varepsilon}|=\boldsymbol{\alpha}+\boldsymbol{\beta 1 N P}$. Hasil uji moderasi diperoleh nilai adjusted $\mathrm{R}^{2}$ sebesar -0.008 , nilai f hitung sebesar 0.068 , dan t hitung 0.260 dengan tingkat signifikansi 0.795 lebih besar dari 0.05 , maka dapat disimpulkan bahwa variabel komisaris independen bukan merupakan variabel moderasi.

Hasil penelitian ini menunjukkan bahwa komisaris independen bukan sebagai variabel moderasi dari hubungan antara manajemen laba terhadap nilai perusahaan. Komisaris independen terbukti bukan merupakan variabel pemoderasi terhadap hubungan antara variabel manajemen laba dan nilai perusahaan, karena variabel komisaris independen memiliki nilai tidak signifikan sehingga variabel kepemilikan manajerial tidak dikatakan sebagai variabel pemoderasi.

Hasil penelitian ini mendukung hasil penelitian yang dilakukan oleh Herawaty (2008) dan Dyas Tri Pamungkas (2012) yang menyimpulkan bahwa proporsi dewan komisaris independen tidak mempunyai pengaruh yang signifikan terhadap nilai perusahaan, Karena nilai signifikansi berada jauh di atas tingkat signifikansi 0,05 maka dapat dinyatakan bahwa komisaris independen tidak mempunyai hubungan yang signifikan terhadap nilai perusahaan. 


\section{Kualitas audit memoderasi hubungan antara manajemen laba dan nilai perusahaan}

Dibawah ini adalah hasil uji moderasi dalam penelitian ini dapat dilihat pada tabel 4.12 sebagai berikut :

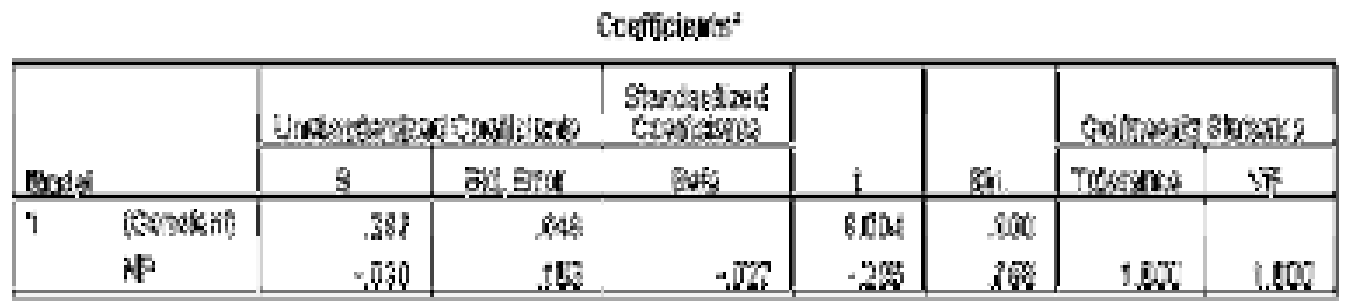

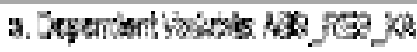

Hipotesis (H5) untuk menguji variabel moderasi memiliki dua model regresi yaitu : $\mathbf{K A}=\boldsymbol{\alpha}+\boldsymbol{\beta 1 M L}$ dan $|\boldsymbol{\varepsilon}|=\boldsymbol{\alpha}+\boldsymbol{\beta 1 N P}$. Hasil uji moderasi diperoleh nilai adjusted $\mathrm{R}^{2}$ sebesar 0.008 , nilai $\mathrm{f}$ hitung sebesar 0.088 , dan $\mathrm{t}$ hitung -0.296 dengan tingkat signifikansi 0.768 lebih besar dari 0.05 , maka dapat disimpulkan bahwa variabel kualitas audit bukan merupakan variabel moderasi.

Hasil penelitian ini menunjukkan bahwa kualitas audit bukan sebagai variabel moderasi dari hubungan antara manajemen laba terhadap nilai perusahaan. Kualitas audit terbukti bukan merupakan variabel pemoderasi terhadap hubungan antara variabel manajemen laba dan nilai perusahaan, karena variabel komisaris independen memiliki nilai tidak signifikan sehingga variabel kepemilikan manajerial tidak dikatakan sebagai variabel pemoderasi. Hasil penelitian ini bertentangan dengan hasil penelitian yang dilakukan oleh Herawaty (2008) yang menyimpulkan bahwa kualitas audit dapat mengurangi aktivitas manajemen laba yang dilakukan manajer untuk meningkatkan nilai perusahaan. Hasil penelitian ini juga bertentangan dengan hasil penelitian yang dilakukan oleh Meutia (2004) yang menyatakan bahwa kualitas audit yang dilihat dari tingkat independensi auditor dan kualitas KAP berpengaruh negatif terhadap manajemen laba.

\section{PENUTUP}

\section{Kesimpulan}

penelitian ini bertujuan untuk mengetahui pengaruh manajemen laba,kepemilikan manajerial, institusional, komisaris independen, dan kualitas audit terhadap nilai perusahaan. Berdasarkan hasil yang diperoleh dari pengolahan dan analisis data dengan bantuan alat SPSS 16.0, maka hasil penelitian ini menunjukkan bahwa :

1. Variabel manajemen laba tidak berpengaruh signifikan terhadap nilai perusahaan sedangkan ukuran perusahaan juga tidak berpengaruh terhadap nilai perusahaan.

2. Variabel kepemilikan manajerial terbukti merupakan variabel pemoderasi terhadap hubungan antara variabel manajemen laba dan nilai perusahaan, karena variabel kepemilikan manajerial memiliki nilai signifikan sehingga variabel kepemilikan manajerial dapat dikatakan sebagai variabel pemoderasi.

3. Variabel kepemilikan institusional terbukti sebagai variabel moderasi dari hubungan antara manajemen laba dan nilai perusahaan memiliki pengaruh. Hal ini berarti jumlah kepemilikan saham oleh institusional berpengaruh terhadap hubungan antara manajemen laba dan nilai perusahaan.

4. Variabel komisaris independen tidak terbukti sebagai variabel moderasi dari hubungan antara manajemen laba dan nilai perusahaan, karena variabel komisaris independen memiliki nilai 
tidak signifikan sehingga komisaris independen di dalam struktur dewan komisaris perusahaan tidak berpengaruh terhadap hubungan antara manajemen laba dan nilai perusahaan

5. Variabel kualitas audit tidak terbukti sebagai variabel moderasi dari hubungan antara manajemen laba dan nilai perusahaan, karena variabel kualitas audit memiliki nilai tidak signifikan sehingga variabel kualitas audit tidak dikatakan sebagai variabel pemoderasi sehingga kualitas audit KAP tidak berpengaruh terhadap hubungan antara manajemen laba dan nilai perusahaan.

\section{Saran}

Saran-saran yang dapat diberikan untuk penelitian selanjutnya adalah membedakan tahun penerapan corporate governance dengan tahun nilai perusahaan, memasukkan corporate governance yang lain sebagai variabel moderasi seperti komite audit, ukuran dewan komisaris, jumlah pertemuan rapat pemegang saham atau kompensansi eksekutif, serta memperpanjang periode pengamatan untuk mendapatkan hasil penelitian yang lebih bervariasi.

\section{DAFTAR PUSTAKA}

Dyas Tri Pamungkas. 2012. "Pengaruh Earnings Management Terhadap Nilai Perusahaan Dengan Corporate Governance Sebagai Variabel Pemoderasi”. Jurnal Akuntansi dan Keuangan.

Soerzawa, D., Yusmaniarti, \& Suhendra, C. (2018). Pengaruh Penghindaran Pajak terhadap

Nilai Perusahaan dengan Leverage sebagai Variabel Moderasi. BILANCIA: Jurnal Ilmiah Akuntansi, 2(4), 367-377.

Eisenhardt, K.M. 1989. " Agency Theory: An Assessement and Review” Academy Of Management Review, Vol. 14. No. 1.

Gumanti, T. A. 2000. "Earningss Management: Suatu Telaah Pustaka". Jurnal Akuntansi dan Keuangan, Vol. 2, No. 2, November $2000: 104-115$.

Haruman, Tendi. 2008. "Pengaruh Struktur Kepemilikan terhadap Keputusan Keuangan dan Nilai Perusahaan". Simposium Nasional Akuntansi XI, Pontianak.

Healy, Paul M, \& James M, Wahlen, 1998, “ A Review Of The Earnings Management Literature And Its Implications for Standard Setting”, Working paper.

Herawaty, V. 2008. "Peran Praktik Corporate Governance sebagai Moderating Variabel dari Pengaruh Earningss Management terhadap Nilai Perusahaan”. Simposium Nasional Akuntansi IX. Pontianak.

Imam Ghozali. 2009. Aplikasi Analisis Multivariate dengan Program SPSS. Semarang: Badan Penerbit Universitas Diponegoro.

Midiastuty, Pratana Puspa dan Mas'ud Machfoedz. 2003. "Analisa Hubungan Mekanisme Corporate Governance dan Indikasi Manajemen Laba". Simposium Nasional Akuntansi VI. Surabaya.

Murhadi, Werner R. 2009. "Good Corporate Governance and Earnings Management Practices: An Indonesian Cases". http://ssrn.com. 
Ujiyantho, Muh. Arief dan Pramuka, Bambang Agus. 2007. "Mekanisme Corporate Governance, Manajemen Laba, dan Kinerja Keuangan". Simposium Nasional Akuntansi X, Makassar, 26-28 Juli 2007.

Yusmaniarti, Yusmaniarti; Setiorini, H. P. (2019). Influence PENGARUH GOOD CORPORATE GOVERNANCE, PROFITABILITAS, DAN LEVERAGE TERHADAP NILAI PERUSAHAAN PADA PERUSAHAAN PROPERTY DAN REAL ESTATE INDONESIA. Bilancia: Jurnal Ilmiah Akuntansi, 3(4), 406-418. https://doi.org/10.4018/ijpada.2016010103

Yusmaniarti, Yusmaniarti, A. B. (2020). Pengaruh Penerapan Good Corporate Governance, Independensi Auditor Dan Kualitas Audit Terhadap Nilai Perusahaan. Jurnal Sains Manajemen Dan Bisnis Indonesia, 10(1), 50-67.

Wahyudi, Untung dan Hartini P. Pawestri. 2006. Implikasi Struktur Kepemilikan Terhadap Nilai Perusahaan: Dengan Keputusan Keuangan Sebagai Variabel Intervening. Simposium Nasional Akuntansi (SNA) IX Padang. 